\title{
Specific and non-specific folate binding protein in normal and malignant human tissues
}

\author{
R. CORROCHER ${ }^{1}$, G. De SANDRE, A. AMBROSETTI, M. L. PACHOR, \\ L. M. BAMBARA, AND A. V. HOFFBRAND
}

From the Instituto di Patologia Medica II, Università di Padova, Italy and the Department of Haematology, Royal Free Hospital, London, UK

SUMMARY Binding of tritiated folic acid by supernatants prepared from extracts of normal and leukaemic leucocytes, normal mucosa, and malignant tumours from different parts of the gastrointestinal tract has been measured using Sephadex-gel filtration and albumin-coated charcoal techniques. Non-specific binding (measured by Sephadex G-75 gel filtration) was almost invariably greater than specific binding measured by albumin-coated charcoal separation of bound and unbound folate. In nine normal leucocyte extracts, binding measured by Sephadex G-75 filtration ranged from 1.3 to 18.2 (mean 8.2 ) $\mathrm{pg} / \mathrm{mg}$ protein and by albumin-coated charcoal from 1.0 to 14.8 (mean 6.7) $\mathrm{pg} / \mathrm{mg}$ protein. Raised specific binding was found in the extracts from leucocytes of eight of 14 patients with chronic granulocytic leukaemia, in four substantially so $(389,121,108$, $59.7 \mathrm{pg} / \mathrm{mg}$ protein), but was only marginally increased in one of eight cases of acute myeloid leukaemia and in two of five cases of chronic lymphocytic leukaemia. Binding was normal in the extracts of all three cases of acute lymphoblastic leukaemia tested.

Among the tissues of the gastrointestinal tract binding was greatest by the duodenal mucosa and liver. Extracts of carcinoma of the stomach and colon bound greater amounts of ${ }^{3} \mathrm{H}$-folic acid than the corresponding normal mucosal extracts but the differences were not large. Sephadex G-200 gel chromatography showed more than one binding peak in the extracts of liver and duodenum but only one peak in the other tissues of the gastrointestinal tract, and only one peak, of molecular weight either about 50000 or over 200 000, in the leucocyte extracts.

The presence of a folate binding protein (FABP) in human tissues was first demonstrated by Rothenberg (1970) in the leucocytes of some patients with chronic granulocytic leukaemia. Subsequently, a folate binding protein was found in granulocytes of women who were pregnant or taking oral contraceptives (Da Costa and Rothenberg, 1974a) and in the sera of normal subjects and patients with a variety of diseases (Rothenberg, 1973; Waxman and Schreiber, 1973; Zettner and Duly, 1974; Colman and Herbert, 1976; Gorst et al., 1976; Rothenberg and $\mathrm{Da}$ Costa, 1976).

In these studies it was not always clear whether the binding of ${ }^{3} \mathrm{H}$-folic acid $\left({ }^{3} \mathrm{H}-\mathrm{PteGlu}\right)$ was specific or non-specific in nature. As recently pointed out by Rothenberg and Da Costa (1976), at physiological

${ }^{1}$ Correspondence to: Dr R. Corrocher, Instituto di Patologia Medica II, Policlinico Borgo Roma, Verona, Italy. Received for publication 1 December 1977
$\mathrm{pH}$ the glutamic acid part of the folate molecule is negatively charged $\left(-\mathrm{COO}^{-}\right)$so that it tends to bind non-specifically to molecules with a positive radical (as $\mathrm{NH}_{3}+$ ). This non-specific binding is characterised by low affinity and fails to demonstrate saturation kinetics. In contrast, specific binding has a high affinity for the ligand and demonstrates saturation kinetics. It depends on the characteristic structure of the molecule and it involves, in the case of folate, the pteridine moiety. This specific binding, in contrast to the non-specific binding, cannot be dissociated by short exposure to albumin-coated charcoal (Rothenberg and Da Costa, 1976).

The aim of the present study was to detect and quantitate the unsaturated folate binding activity in various normal and malignant human tissues, and to compare specific and non-specific folate binding capacities of these tissues. A preliminary report of some of this work has already been published (Corrocher et al., 1976). 


\section{Material and methods}

\section{LEUCOCYTES AND TISSUES}

Leucocytes of 14 patients with chronic granulocytic leukaemia (CGL), eight patients with acute myeloblastic leukaemia (AML), five patients with chronic lymphocytic leukaemia (CLL), three patients with

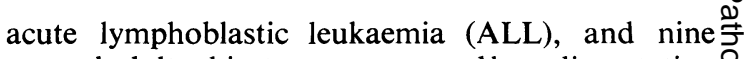
normal adult subjects were recovered by sedimentation 은 ( $2 \mathrm{~h}$ at room temperature) of heparinised blood mixed $\Rightarrow$ with Emagel $(1: 1 \mathrm{v} / \mathrm{v})$, and washed three times with cold $\left(4^{\circ} \mathrm{C}\right)$ physiological saline. The clinical and haematological data on these patients with leukaemia are listed in Tables 1 and 2 . Tissues from different

Table 1 Clinical data and tritiated folic acid $\left({ }^{3} \mathrm{H}\right.$-PteGlu) binding capacity of peripheral blood leucocytes from normal subjects and from patients with acute myeloid leukaemia $(A M L)$ and acute lymphoblastic leukaemia $(A L L)$

\begin{tabular}{|c|c|c|c|c|c|c|c|c|c|c|c|}
\hline \multirow{2}{*}{\multicolumn{2}{|c|}{ Case }} & \multirow[t]{2}{*}{ Age } & \multirow[t]{2}{*}{$\operatorname{Sex}$} & \multirow[t]{2}{*}{$H b(g / d l)$} & \multirow[t]{2}{*}{$W B C \times 10^{9} / l$} & \multirow[t]{2}{*}{$\%$ Blasts } & \multirow[t]{2}{*}{ Diagnosis } & \multirow[t]{2}{*}{ Treatment } & \multicolumn{2}{|c|}{${ }^{3} \mathrm{H}$-PteGlu binding } & \multirow{2}{*}{$\begin{array}{l}\text { Cold PteGlu } \\
\text { inhibition (using } \\
\text { ACC) }(\%)\end{array}$} \\
\hline & & & & & & & & & $\begin{array}{l}p g / m g \text { Protein } \\
S-G 75\end{array}$ & $\begin{array}{l}p g / m g \text { Protein } \\
A C C\end{array}$ & \\
\hline 1 & (RC) & 24 & $\mathbf{M}$ & 13.9 & $7 \cdot 5$ & - & Normal & - & $18 \cdot 2$ & $14 \cdot 8$ & $100 \cdot 0$ \\
\hline 2 & (BG) & 26 & $\mathbf{M}$ & $14 \cdot 7$ & $5 \cdot 8$ & - & Normal & - & $10 \cdot 3$ & $7 \cdot 4$ & $98 \cdot 2$ \\
\hline 3 & (AN) & 29 & $F$ & 13.5 & $8 \cdot 2$ & - & Normal & - & $9 \cdot 7$ & $6 \cdot 7$ & - \\
\hline 4 & (FG) & 62 & $\mathbf{M}$ & $12 \cdot 8$ & $7 \cdot 6$ & - & Normal & - & $8 \cdot 4$ & $6 \cdot 5$ & - \\
\hline 5 & (OP) & 35 & $F$ & $13 \cdot 1$ & 6.9 & - & Normal & $\ldots$ & $8 \cdot 2$ & $5 \cdot 8$ & $99 \cdot 1$ \\
\hline 6 & (VT) & 20 & $\mathbf{M}$ & $14 \cdot 8$ & $9 \cdot 3$ & - & Normal & - & $6 \cdot 7$ & $7 \cdot 6$ & - \\
\hline 7 & (PM) & 48 & $F$ & $12 \cdot 2$ & $6 \cdot 4$ & - & Normal & - & $6 \cdot 6$ & $6 \cdot 5$ & - \\
\hline 8 & (BF) & 47 & $\mathbf{M}$ & 15.6 & 6.9 & - & Normal & - & $4 \cdot 5$ & $4 \cdot 1$ & - \\
\hline 9 & (MG) & 33 & $\mathrm{~F}$ & $13 \cdot 0$ & $5 \cdot 8$ & - & Normal & - & $1 \cdot 3$ & 1.0 & - \\
\hline 1 & $(\mathrm{LA})$ & 27 & $\mathbf{M}$ & $8 \cdot 7$ & 24 & 97 & AML & No & $20 \cdot 9$ & $14 \cdot 8$ & $99 \cdot 4$ \\
\hline 2 & (RS) & 55 & $\mathbf{M}$ & $7 \cdot 4$ & 120 & 92 & AML & No & $17 \cdot 0$ & $18 \cdot 0$ & 86.4 \\
\hline 3 & (BP) & 26 & $\mathbf{M}$ & $8 \cdot 8$ & 13 & 38 & AML & No & $17 \cdot 0$ & $10 \cdot 2$ & - \\
\hline 4 & (TG) & 71 & $\mathbf{M}$ & $4 \cdot 6$ & 54 & 93 & AML & No & $13 \cdot 8$ & $7 \cdot 1$ & - \\
\hline \multirow[t]{2}{*}{7} & $(F V)^{a}$ & 67 & $\mathbf{M}$ & $8 \cdot 8$ & 38 & 87 & AML & No & $3 \cdot 7$ & 0.9 & $90 \cdot 1$ \\
\hline & $(F V)^{b}$ & & & $9 \cdot 0$ & 46 & 88 & AML & Yes* & $3 \cdot 7$ & $2 \cdot 8$ & - \\
\hline 8 & (SG) & 69 & $\mathbf{M}$ & $5 \cdot 3$ & 120 & 88 & AML & No & - & 0.76 & - \\
\hline 1 & $(\mathrm{MC})$ & 31 & $\mathrm{~F}$ & $9 \cdot 1$ & 131 & 80 & ALL & No & $37 \cdot 6$ & $7 \cdot 9$ & $97 \cdot 3$ \\
\hline 2 & (GL) & 34 & $\mathbf{F}$ & 10.6 & 170 & 96 & ALL & No & $14 \cdot 1$ & $12 \cdot 0$ & 89.9 \\
\hline 3 & (ZL) & 29 & $\mathbf{M}$ & 81 & 38 & 95 & ALL & No & - & 0.0 & - \\
\hline
\end{tabular}

S-G75 = Sephadex G-75; ACC = albumin-coated charcoal (also in Tables 2 and 3)

*Treatment = thioguanine, daunorubicin, cytosine, arabinoside, prednisone (TRAP)

Table 2 Clinical data and tritiated folic acid $\left({ }^{3} \mathrm{H}\right.$-PteGlu) binding capacity of peripheral blood leucocytes from patients with chronic granulocytic leukaemia $(C G L)$ and chronic lymphocytic leukaemia $(C L L)$

\begin{tabular}{|c|c|c|c|c|c|c|c|c|c|c|c|}
\hline \multicolumn{2}{|c|}{ Case } & \multirow{2}{*}{$\begin{array}{l}\text { Age } \\
24\end{array}$} & \multirow{2}{*}{$\begin{array}{l}\begin{array}{l}H b \\
(g / d l)\end{array} \\
7 \cdot 6\end{array}$} & \multirow{2}{*}{$\begin{array}{l}W B C \\
\times 10^{9} / d l \\
79\end{array}$} & \multirow{2}{*}{$\begin{array}{l}P M N(\%) \\
54\end{array}$} & \multirow{2}{*}{$\begin{array}{l}\text { Blasts }(\%) \\
-\end{array}$} & \multirow{2}{*}{$\begin{array}{l}\text { Diagnosis } \\
\text { CGL }\end{array}$} & \multirow{2}{*}{$\begin{array}{l}\text { Treatment } \\
\text { No }\end{array}$} & \multirow{2}{*}{$\begin{array}{l}\text { pg/mg Protein } \\
S-G 75 \\
689\end{array}$} & \multirow{2}{*}{$\begin{array}{l}\text { pg/mg Protein } \\
A C C \\
108\end{array}$} & \multirow{2}{*}{$\begin{array}{l}\text { Cold folate \% } \\
\text { inhibition (using } \\
\text { ACC) } \\
98 \cdot 8\end{array}$} \\
\hline 1 & (PS) & & & & & & & & & & \\
\hline 2 & (PM) & 17 & $11 \cdot 6$ & 155 & 50 & 4 & CGL & No & 450 & 389 & $87 \cdot 5$ \\
\hline 3 & (VT) & 70 & $8 \cdot 8$ & 120 & 49 & 15 & CGL & No & 218 & 122 & - \\
\hline \multirow[t]{2}{*}{4} & $(Z M)^{a}$ & 45 & $9 \cdot 5$ & 104 & 27 & 24 & CGL & No & $71 \cdot 5$ & $59 \cdot 7$ & - \\
\hline & $(Z M)^{b}$ & 46 & $10 \cdot 5$ & 62 & 46 & 5 & CGL & Busulphan & 129 & 103 & - \\
\hline \multirow[t]{3}{*}{5} & $(F V)^{a}$ & 53 & $8 \cdot 4$ & 160 & 65 & - & CGL & No & $48 \cdot 9$ & $9 \cdot 3$ & - \\
\hline & $(F V)^{b}$ & 54 & 8.0 & 125 & 66 & - & CGL & Busulphan & $13 \cdot 1$ & - & - \\
\hline & $(F V)^{c}$ & 54 & $9 \cdot 3$ & 103 & 44 & 4 & CGL & Busulphan & $7 \cdot 1$ & $10 \cdot 3$ & - \\
\hline 6 & $(\mathrm{MN})$ & 53 & $9 \cdot 4$ & 87 & 64 & 7 & CGL & No & $38 \cdot 6$ & $9 \cdot 2$ & $84 \cdot 9$ \\
\hline 7 & (DS) & 20 & $13 \cdot 5$ & 116 & 63 & - & CGL & No & $25 \cdot 4$ & 18.9 & - \\
\hline 8 & (TA) & 50 & $8 \cdot 6$ & 138 & 66 & - & CGL & No & $24 \cdot 4$ & $13 \cdot 7$ & 100 \\
\hline 9 & (PV) & 52 & $7 \cdot 6$ & 132 & 72 & 6 & CGL & No & $16 \cdot 1$ & $18 \cdot 7$ & $92 \cdot 2$ \\
\hline 10 & (SF) & 18 & $9 \cdot 5$ & 350 & 28 & 8 & CGL & No & $14 \cdot 7$ & $20 \cdot 1$ & $93 \cdot 7$ \\
\hline 11 & (SP) & 27 & $8 \cdot 4$ & 52 & 42 & 17 & CGL & No & $9 \cdot 3$ & $8 \cdot 7$ & - \\
\hline 12 & (CI) & 33 & $9 \cdot 0$ & 85 & 54 & 12 & CGL & No & $7 \cdot 0$ & $7 \cdot 9$ & 100 \\
\hline 13 & (RO) & 52 & $11 \cdot 5$ & 49 & 85 & - & CGL & No & $4 \cdot 4$ & $1 \cdot 8$ & - \\
\hline \multirow[t]{2}{*}{14} & (PA) & 37 & $8 \cdot 1$ & 34 & 25 & 37 & CGL & No & $2 \cdot 1$ & $1 \cdot 7$ & - \\
\hline & & & & & $P M N(\%)$ & $\begin{array}{l}\text { Lympho- } \\
\text { cytes }(\%)\end{array}$ & & & & & \\
\hline 1 & (BF) & 76 & $10 \cdot 2$ & 90 & 2 & 98 & CLL & No & $38 \cdot 7$ & $23 \cdot 7$ & - \\
\hline 2 & (LA) & 50 & $9 \cdot 7$ & 100 & 1 & 99 & CLL & No & $32 \cdot 7$ & $17 \cdot 2$ & - \\
\hline 3 & (RA) & 70 & $11 \cdot 8$ & 52 & 6 & 94 & CLL & No & $22 \cdot 6$ & $8 \cdot 6$ & - \\
\hline 4 & (TR) & 62 & $8 \cdot 4$ & 93 & 11 & 89 & CLL & No & - & 0 & - \\
\hline 5 & (BG) & 69 & $13 \cdot 4$ & 138 & 5 & 95 & CLL & No & - & $5 \cdot 4$ & - \\
\hline
\end{tabular}


Table 3 Tritiated folic acid $\left({ }^{3} \mathrm{H}\right.$-PteGlu) binding of supernatants prepared from normal and malignant tissues of the gastrointestinal tract

\begin{tabular}{|c|c|c|c|c|c|c|c|}
\hline \multirow[t]{2}{*}{ Case } & & \multirow[t]{2}{*}{ Age } & \multirow[t]{2}{*}{ Sex } & \multirow[t]{2}{*}{ Tissue } & \multicolumn{2}{|l|}{${ }^{3} \mathrm{H}$-PteGlu binding } & \multirow{2}{*}{$\begin{array}{l}\text { Cold PteGlu inhibition } \\
\text { (using } A C C)(\%)\end{array}$} \\
\hline & & & & & pg/mg Protein S-G75 & $p g / m g$ Protein $A C C$ & \\
\hline 1 & (CR) & 58 & $\mathbf{M}$ & Oesophagus & $22 \cdot 5$ & $10 \cdot 1$ & - \\
\hline 2 & (VB) & 49 & $\mathbf{M}$ & Stomach (fundus) & $15 \cdot 2$ & $10 \cdot 1$ & - \\
\hline 3 & (GB) & 49 & $\mathbf{M}$ & Duodenum & $67 \cdot 2$ & $46 \cdot 8$ & $94 \cdot 3$ \\
\hline 4 & (RT) & 61 & $\mathbf{M}$ & Colon & $52 \cdot 8$ & $31 \cdot 4$ & - \\
\hline 5 & (GF) & 54 & $\mathbf{M}$ & Liver & $72 \cdot 1$ & $51 \cdot 4$ & $97 \cdot 5$ \\
\hline 6 & (BL) & 57 & $\mathbf{M}$ & Adenocarcinoma of oesophagus & $77 \cdot 5$ & $29 \cdot 1$ & - \\
\hline 7 & (BM) & 53 & $\mathbf{M}$ & Carcinoma (squamous) of oesophagus & $77 \cdot 4$ & - & 一 \\
\hline 8 & (GG) & 61 & $\mathbf{M}$ & Adenocarcinoma of stomach (cardia) & $28 \cdot 3$ & $18 \cdot 0$ & - \\
\hline 9 & (DG) & 49 & $\mathbf{M}$ & Adenocarcinoma of stomach (fundus) & $21 \cdot 3$ & $11 \cdot 1$ & - \\
\hline 10 & (PA) & 54 & $\mathbf{M}$ & Adenocarcinoma of colon & $60 \cdot 7$ & $33 \cdot 8$ & - \\
\hline 11 & (SC) & 59 & $\mathbf{M}$ & Adenocarcinoma of rectum & $63 \cdot 8$ & $33 \cdot 8$ & - \\
\hline 12 & (MC) & 58 & $\mathbf{M}$ & Carcinoma (mucus secreting) of rectum & $37 \cdot 2$ & $23 \cdot 8$ & - \\
\hline
\end{tabular}

parts of the gastrointestinal tract were obtained during laparotomy with the informed consent of the patient as follows. Histologically normal mucosa of oesophagus and colon was taken at operations to remove cancer of these organs (Table 3). Duodenal mucosa was taken at operation for a benign duodenal ulcer; gastric and cardia mucosae were taken at operation for peptic ulceration of the pylorus. Liver biopsy was obtained during cholecystectomy for calculi.

The tissues were plunged into cold $\left(4^{\circ} \mathrm{C}\right)$ phosphate buffered saline (PBS) and washed free of blood, and, where appropriate, the mucosa was scraped onto a cold glass slide.

\section{PREPARATION OF SUPERNATANTS}

The leucocytes and mucosal samples were suspended in sodium citrate buffer, $\mathrm{pH} \mathrm{8.5,0.05} \mathrm{M}$ (Rothenberg, 1970), and lysed after thawing and freezing three times (leucocytes) or homogenised (tissues) in the same buffer using a Teflon-coated Potter-Elvejehm homogeniser, and centrifuged at $110000 \mathrm{~g}$ for two hours. The particle-free supernatants were removed and stored at $-20^{\circ} \mathrm{C}$ until used.

\section{CHROMATOGRAPHIC STUDIES}

To study the unsaturated folate binding capacity (UFBC), $0.2 \mathrm{ml}$ of each supernatant was incubated in $0.3 \mathrm{ml}$ of $0.05 \mathrm{M}$ sodium citrate buffer, $\mathrm{pH} 8.5$, with $20 \mu \mathrm{l}(5.96 \mathrm{ng})$ of generally labelled ${ }^{3} \mathrm{H}$-folic acid ( ${ }^{3} \mathrm{H}-\mathrm{PteG}$ (u), specific activity $40 \mathrm{mCi} / \mathrm{mmol}$ (Radiochemical Centre, Amersham), for $15 \mathrm{~min}$ at $37^{\circ} \mathrm{C}$ and then chromatographed on a Sephadex G-75 column $(0.5 \times 31 \mathrm{~cm})$. Thirty $0.5-\mathrm{ml}$ fractions were collected in counting vials containing $0.4 \mathrm{ml}$ of Instagel (Packard). The radioactivity of each sample was determined in a liquid scintillation beta-counter (Packard). Aliquots of the supernatants incubated with ${ }^{3} \mathrm{H}-\mathrm{PteGlu}$ were also chromatographed on a Sephadex G-200 column $(90 \times 2.0 \mathrm{~cm})$ previously equilibrated with the sodium citrate buffer. One hundred and twenty $5-\mathrm{ml}$ fractions were collected, and the radioactivity of $0.5-\mathrm{ml}$ aliquots was measured and plotted against protein concentrations.

The columns were calibrated with blue dextran (MW 2000000), albumin (MW 64000 ), or haemoglobin (MW 68000 ) and ${ }^{3} \mathrm{H}-\mathrm{PteGlu}(\mathrm{MW} 441$ ) by measuring the optical density $(280$ or $560 \mathrm{~nm}$ ) or the radioactivity.

\section{CHARCOAL ADSORPTION STUDIES}

Albumin-coated charcoal was prepared by mixing equal volumes of a Norit $A$ suspension $(5 \mathrm{~g}$ in $100 \mathrm{ml}$ distilled water) and $1 \%$ aqueous solution of bovine albumin (Sigma). $0.5 \mathrm{ml}$ of each supernatant was incubated with $20 \mu \mathrm{l}(290 \mathrm{pg})$ of ${ }^{3} \mathrm{H}-\mathrm{Pte}-$ Glu in distilled water for $1 \mathrm{~h}$ at $37^{\circ} \mathrm{C}$; then $0.7 \mathrm{ml}$ of the albumin-coated charcoal was added to the samples and stirred for $\mathbf{1 0} \mathrm{min}$. The coated charcoal was removed by centrifugation $(10000 \mathrm{rpm}, 10 \mathrm{~min})$ and the radioactivity of $0.5 \mathrm{ml}$ of the remaining supernatant was measured; the radioactivity of a charcoal control, in which sodium citrate instead of supernatant was incubated with ${ }^{3} \mathrm{H}-\mathrm{PteGlu}$, was subtracted from each result. Each experiment was performed in triplicate, and the results between tubes over all experiments varied by a mean of $5.6 \%$ with a maximum of $12.6 \%$.

\section{INHIBITION OF BINDING OF TRITIATED}

FOLIC ACID BY COLD FOLIC ACID

Aliquots of the supernatants were preincubated for $30 \mathrm{~min}$ at $37^{\circ} \mathrm{C}$ with $2 \mu \mathrm{g}$ of cold PteGlu before the addition of $290 \mathrm{pg}$ of ${ }^{3} \mathrm{H}-\mathrm{PteGlu}$; then albumincoated charcoal was added, and the experiment described above was repeated.

\section{KINETIC STUDIES}

$0.2 \mathrm{ml}$ (306 $\mu \mathrm{g}$ of protein) of the peak folate binding fraction on Sephadex G-200 of a CGL supernatant 
was incubated with increasing amounts of ${ }^{3} \mathrm{H}-\mathrm{PteGlu}$, ranging from 5.9 to $5960 \mathrm{pg}$. The amount of folate bound was determined using coated charcoal.

\section{Results}

\section{SEPHADEX G-75 CHROMATOGRAPHY}

The chromatographic profile, after addition of ${ }^{3} \mathrm{H}-\mathrm{PteGlu}$ to leucocyte supernatants, was invariably characterised by two radioactive peaks, the earlier peak being due to protein bound folate, the later peak being free folate (Fig. 1). Tables 1 to 3 show the amount of ${ }^{3} \mathrm{H}-\mathrm{PteGlu}$ bound per milligram of protein by supernatants from various tissues using this technique. The values for the UFBC of nine normal leucocyte preparations ranged from 1.27 to 18.7 (mean $8 \cdot 2$ ) $\mathrm{pg} / \mathrm{mg}$ protein (Table 1). Similar results were obtained using supernatants from eight leucocyte preparations from AML, only one sample being slightly above normal (Table 1 ). On the other hand, using supernatants from two patients with ALL and three with CLL, the mean values were higher, being $25 \cdot 8$ and $31.3 \mathrm{pg} / \mathrm{mg}$ protein respectively (Tables 1 and 2).

The results obtained using supernatants from peripheral leucocytes of 14 patients with CGL are given in Table 2. Two of them (FV and ZM) were studied before $(a)$ and after $(b, c)$ therapy. In eight of the 14 patients the amount of folate bound was above the normal range, and in four the amount of folate bound was over $100 \mathrm{pg} / \mathrm{mg}$ (Table 2).

Among the tissues from the gastrointestinal tract, UFBC was highest in the duodenal mucosa $(67.2 \mathrm{pg} / \mathrm{mg}$ protein) and liver $(72 \cdot 2 \mathrm{pg} / \mathrm{mg})$, and was progressively lower in the colon $(52.8 \mathrm{pg} / \mathrm{mg})$, oesophagus $(22 \cdot 5 \mathrm{pg} / \mathrm{mg})$, and stomach $(15 \cdot 2 \mathrm{pg} / \mathrm{mg})$. In tumours derived from different parts of the gastrointestinal tract, the UFBC was invariably greater (although not markediy so) than that of the corresponding normal mucosa (Table 3 ).

SEPHADEX G-200 CHROMATOGRAPHY Using this system, there was a wide variation in the pattern of elution peaks between different tissues. Indeed, the chromatographic profile of ${ }^{3} \mathrm{H}-\mathrm{PteGlu}$ incubated with the cytoplasm of CGL leucocytes from two patients showed different patterns: in the is first case (FV) (Fig. 2) there was a single small $\vec{\circ}$ peak in the exclusion peak, suggesting a binder of $\rightarrow$ MW greater than 200000 , whereas in the second $\vec{\omega}$ case (PM) (Fig. 3) a single large peak eluted just later than haemoglobin, suggesting an MW of about 50000 . On the same column, liver and duodenal

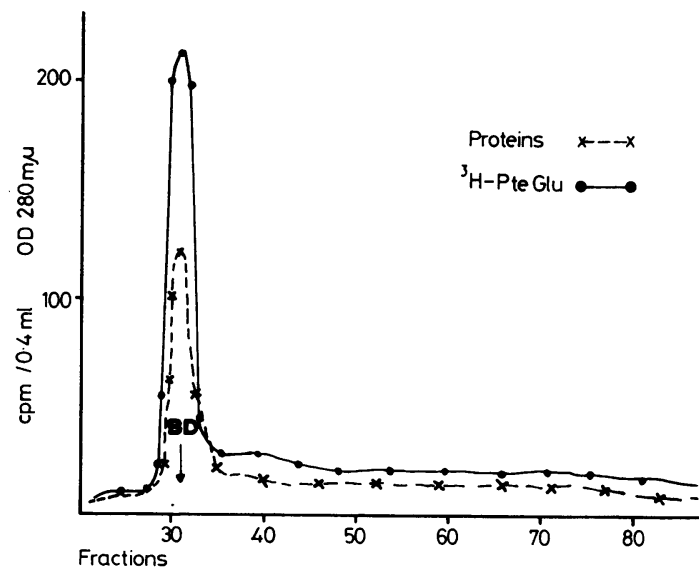

Fig. 2 Elution pattern of ${ }^{3} \mathrm{H}$-PteGlu incubated with the supernatant of leucocytes from a patient with CGL (before treatment $)(F V) . B D=$ blue dextran. Free ${ }^{3} \mathrm{H}$-PteGlu eluted from the Sephadex G-200 column with a peak at fraction 120 and is therefore not shown in Figs 2, 3, or 4.
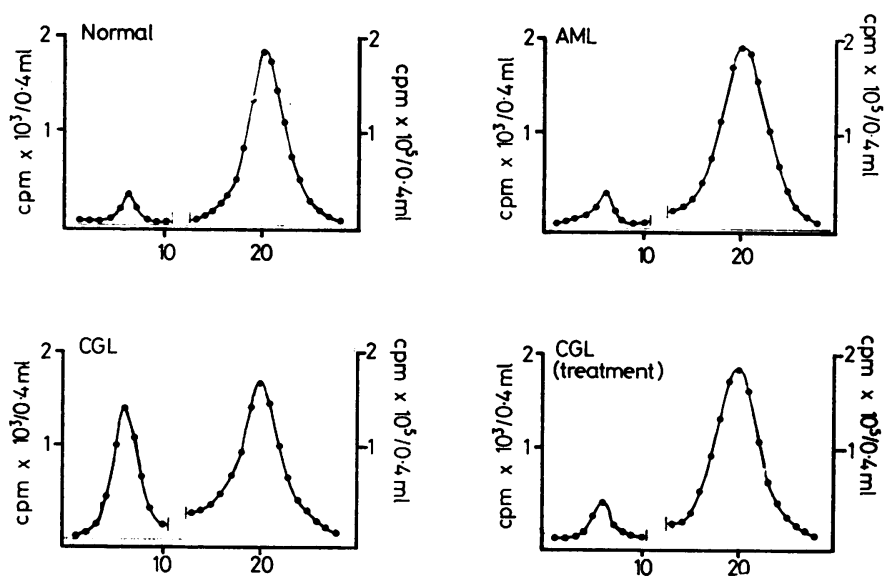

Fig. 1 Chromatographic patterns on Sephadex $\mathrm{G}-75$ after addition of ${ }^{3} \mathrm{H}$-PteGlu to lysates prepared from peripheral leucocytes of a typical normal subject and patients with acute myeloblastic leukaemia (AML) and chronic granulocytic leukaemia $(C G L)$. This $C G L$ patient $(F V)$ was restudied after treatment. The first peak represents the bound folate, whereas the second represents the free folate. Horizontal scale = fraction number. Left-hand ordinate scale $\left(\mathrm{cpm} \times 10^{3} / 0.4 \mathrm{ml}\right)$ refers to counts in peak 1 , and right-hand ordinate scale (cpm $\times$ $10^{5} / 0.4 \mathrm{ml}$ ) refers to counts in peak 2 . 


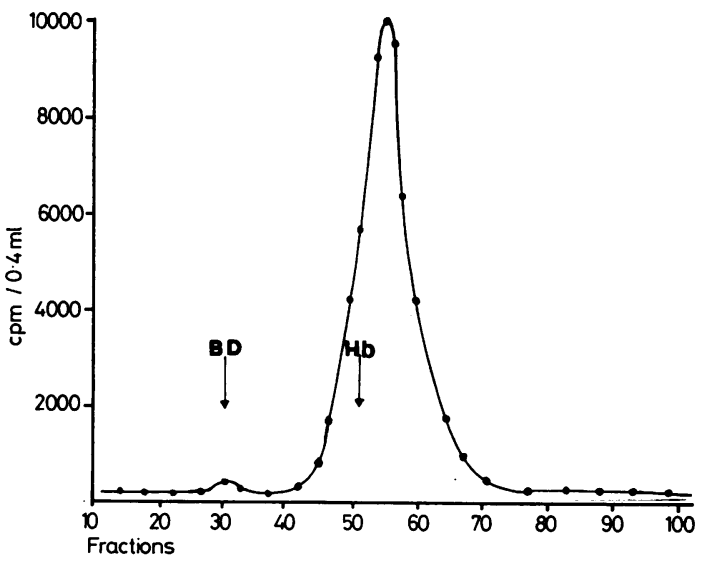

Fig. 3 Elution pattern of ${ }^{3} \mathrm{H}$-PteGlu incubated with the supernatant of an untreated patient $(P M)$ with $C G L$. $B D=$ blue dextran; $\mathrm{Hb}=$ haemoglobin.

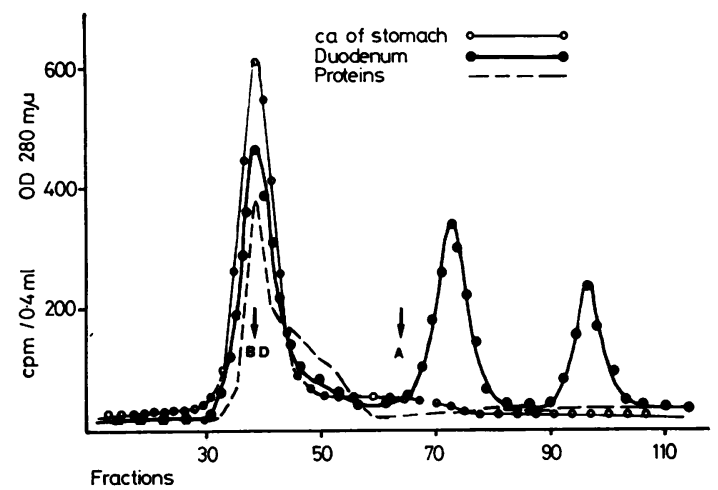

Fig. 4 Elution of ${ }^{3} \mathrm{H}$-PteGlu incubated with supernatants prepared from normal duodenum and from $a$ carcinoma of stomach (case 10, Table 3). Protein pattern is for duodenal supernatant. The protein pattern for the carcinoma supernatant was similar. $B D=b l u e$ dextran; $A=$ albumin.

supernatants showed three radioactive peaks, the first being in the exclusion peak of protein (Fig. 4). These patterns differed from those obtained using a carcinoma of stomach supernatant or supernatant from other tumours which showed only one peak.

ALBUMIN-COATED CHARCOAL STUDIES The amount of ${ }^{3} \mathrm{H}-\mathrm{PteGlu}$ bound by the different extracts after treatment with albumin-coated charcoal is shown in Tables 1 to 3. The UFBC using coated charcoal was almost always lower than the binding capacity measured by Sephadex filtration. Among the nine normal leucocyte preparations, binding ranged from 1.0 to 14.8 (mean 6.7 ) $\mathrm{pg} / \mathrm{mg}$ protein. In four cases of CGL, the binding capacity measured by coated charcoal was particularly high, whereas in seven it was normal and in the other three it was slightly above the normal range. In the other kinds of leukaemia (ALL, AML, and CLL), the coated charcoal-resistant folate binding was normal or slightly raised in three cases.

In the gastrointestinal tract, the highest albumincoated charcoal-resistant folate-binding capacity was found in liver and duodenum (51.4 and 46.8 $\mathrm{pg} / \mathrm{mg}$ protein respectively), but some charcoalresistant binding capacity was found also in other parts of the gastrointestinal tract. In all cases tested, albumin-coated charcoal-resistant binding could be inhibited by cold folate (Tables 1 to 3 ). Moreover, the amount of ${ }^{3} \mathrm{H}-\mathrm{PteGlu}$ bound per milligram of protein in one case of CGL was proportional to the amount of ${ }^{3} \mathrm{H}-\mathrm{PteGlu}$ added to the incubation mixture for the first $100 \mathrm{pg}$; it then decreased progressively (Fig. 5).

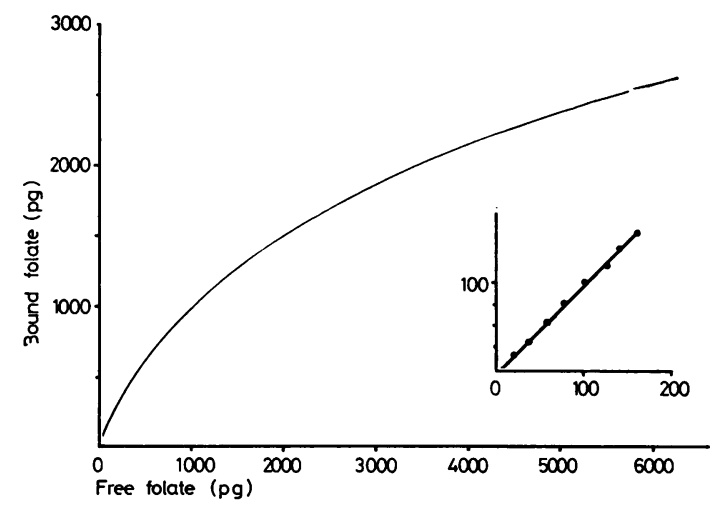

Fig. 5 Saturation curve after addition of increasing amounts of ${ }^{3} \mathrm{H}$-PteGlu to a supernatant from peripheral blood leucocytes in a case of CGL (case 9, Table 2). Inset shows the early part of the saturation curve.

\section{Discussion}

The chromatographic studies carried out using Sephadex G-75 have shown that supernatants from all the tissues studied bind a proportion of added radioactively labelled folic acid. As the cytoplasm of the different tissues contains endogenous folate, the amount of ${ }^{3} \mathrm{H}-\mathrm{PteGlu}$ bound only represents the unsaturated folate binding capacity, provided there is no exchange between the endogenous and added folate. This folic acid binding may be non-specific to proteins normally present in the cell cytoplasm or to proteins derived 
from membranes or other organised structures obtained during the preparation of supernatants.

The results obtained with activated charcoal and the inhibition of this binding by the cold folate suggest that at least in the leucocytes of some cases of chronic granulocytic leukaemia and in some of the other tissues studied, especially duodenum and liver, binding is specific. In the one case of CGL studied (PM) the saturation curve of the binder showed the typical behaviour of specific binding over the range of ${ }^{3} \mathrm{H}-\mathrm{PteGlu}$ used in these experiments (Fig. 5).

A folate-binding protein was first identified in the cytoplasm of leucocytes by Rothenberg (1970). Recently, Rothenberg and colleagues have shown that the binder, which is eluted on Sephadex-gel chromatography as a single peak, is probably a mixture of two binders with a similar molecular weight (Fischer et al., 1975). Moreover, these authors demonstrated that a number of folic acid analogues $\left(\mathbf{H}_{2}\right.$-folate; triglutamate of folic acid; $\mathrm{N}^{10}$ methylfolate; diglutamate of folic acid; and $\mathrm{N}^{5}$-methyl- $\mathrm{H}_{4}$ folate) all inhibit the binding of ${ }^{3} \mathrm{H}-\mathrm{PteGlu}$. This supports the hypothesis that the binder of folic acid, itself an unnatural form of folate, may have biological significance in the metabolism of endogenous natural folates, including polyglutamate forms (Da Costa et al., 1972). On Sephadex G-200the supernatant from the leucocytes of a patient with CGL (FV) showed a small peak of bound folate in the exclusion peak, suggesting an MW of more than 200000 (Fig. 2). A binder of about 50000 MW was not found in this case but was present in the supernatant of the leucocytes of another case (PM) (Fig. 3). The large MW peak may be a different binder; a folate binder of $200000 \mathrm{MW}$ has been isolated from human milk (Waxman and Schreiber, 1974), or it may be due to non-specific binding by protein in the supernatant. It could also be a polymerised form of the smaller MW binders.

The amount of specific (albumin-coated, charcoalresistant) folate-binding protein in some CGL leucocytes was particularly high, whereas in the other types of leukaemia studied, the amount of folate bound in leucocytes did not differ significantly from the normal range. These findings suggest that mature granulocytes and their immediate precursors may be the source of the binder. Previous studies have shown that folate-binding protein may be actively synthesised at a greater than normal rate by chronic granulocytic leukaemia cells (Da Costa and Rothenberg, 1974b). In AML leucocytes, the level of folate binding was invariably normal, even though Gorst et al. (1976) found folate binding to be raised in the sera of patients with AML. The exact cause of this increased serum binding in AML remains to be determined.

In the normal tissues of the gastrointestinal tract, $\stackrel{ }{ }$ the highest concentration of binder was found in $\vec{\Rightarrow}$ duodenal mucosa and in liver cells. On Sephadex $\stackrel{9}{?}$ G-200 the radioactivity after incubation of labelled folic acid with duodenal mucosa supernatant was characterised by three peaks of MWs approximately $\frac{\bar{D}}{\square}$ 200000 or more, 50000 , and 20000 , a pattern $\stackrel{\Phi}{\varrho}$ similar to that described for human, rat, and rabbit liver (Corrocher et al., 1974; Zamierowski and $\overrightarrow{0}$ Wagner, 1974; Markkanen et al., 1975). High molecular weight binding has also been found in the $\vec{\omega}$ intestine of rat and in the brush border of small $\stackrel{?}{\Omega}$ intestine in rat (Leslie and Rowe, 1972; Zamierowski and Wagner, 1974).

The supernatants prepared from some solid $\underset{\nabla}{ }$ tumours were found to contain higher concentrations o of folate binder than the corresponding normal 6 tissues (Table 3). Sephadex G-200 chromatographic 은 analysis in the case of carcinoma of the stomach showed a peak of radioactivity in the exclusion $\subseteq$ peak of proteins, and a similar pattern was found using a colonic mucosa but whether the high MW $\overrightarrow{0}$ protein binder is the main binder at all sites in the 0 gastrointestinal tract remains to be shown.

The different kinds of folate binder suggest that these proteins may have different functions in folate metabolism. Ingested folates are specifically absorbed by duodenal mucosa, and a specific folate mal- $\frac{\mathbb{Q}}{\alpha}$ absorption has been documented in which there is $\Rightarrow$ malabsorption of all forms of folate, including the $\frac{0}{3}$ unphysiological folic acid (Lanzkowsky et al., 1969). It is possible to speculate that the high concentration of binder in duodenal mucosa may be involved in some way in the folate absorptiono mechanism, and a fault in this binding mechanismo is responsible for specific malabsorption of folates (Waxman, 1975). The exact physiological function of the folate-binding proteins, however, remains $₹$ uncertain, and further studies of their in vitro응 binding of natural (reduced) folates and of their $i r l>$ vivo function are needed to elucidate this.

\section{References}

Colman, N., and Herbert, V. (1976). Total folate binding capacity of normal human plasma, and variations in uremia, cirrhosis, and pregnancy. Blood, 48, 911-921

Corrocher, R., De Sandre, G., Pachor, M. L., and Hoff- $\frac{\bar{D}}{\mathscr{D}}$

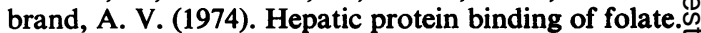
Clinical Science and Molecular Medicine, 46, 551-554. Corrocher, R., Pachor, M. L., Bambara, L. M., Perini,, A., and De Sandre, G. (1976). Folate binding proteins in human digestive system. Rendiconti di Gastro- $\frac{?}{\mathbb{\Phi}}$

Da Costa, M., and Rothenberg, S. P. (1974a). Appearanceo of a folate binder in leukocytes and serum of women 
who are pregnant or taking oral contraceptives. Journal of Laboratory and Clinical Medicine, 83, 207-214.

Da Costa, M., and Rothenberg, S. P. (1974b). Studies of the folate binding factor in cultures and subcellular fractions of chronic myelogenous leukemia cells. Clinical Research, 22, 486A.

Da Costa, M., Rothenberg, S. P., and Kamen, B. (1972). DNA synthesis in chronic myelogenous leukemia cells: Comparison of results in cells containing folate binding factor to replicating cells without binder. Blood, 39, 621-627.

Fischer, C. D., Da Costa, M., and Rothenberg, S. P. (1975). The heterogeneity and properties of folate binding proteins from chronic myelogenous leukaemia cells. Blood, 46, 855-867.

Gorst, D. W., Courtis, M., and Delamore, I. W. (1976). Folic acid binding protein in acute myeloid leukaemia. Journal of Clinical Pathology, 29, 60-62.

Lanzkowsky, P., Erlandson, M. E., and Bezan, A. I. (1969). Isolated defect of folic acid absorption associated with mental retardation and cerebral calcification. Blood, 34, 452-465.

Leslie, G. I. and Rowe, P. B. (1972). Folate binding by the brush border membrane proteins of small intestinal epithelial cells. Biochemistry, 11, 1696-1703.

Markkanen, T., Pajula, R. L., Virtanen, S., Himanen, P., and Jarvinen, M. (1975). Binding of folic acid to serum proteins. V. Tritiated folic acid in the liver. Acta Haematologica, 53, 329-335.
Rothenberg, S. P. (1970). A macromolecular factor in some leukemic cells which binds folic acid. Proceedings of the Society of Experimental Biology and Medicine, 133, 428-432.

Rothenberg, S. P. (1973). Application of competitive ligand binding for the radioassay of vitamin $\mathbf{B}_{12}$ and folic acid. Metabolism, 22, 1075-1082.

Rothenberg, S. P., and Da Costa, M. (1976). Folate binding proteins and radioassay for folate. In Clinics in Haematology, 5, 569-587.

Waxman, S. (1975). Folate binding proteins. British Journal of Haematology, 29, 23-29.

Waxman, S., and Schreiber, C. (1973). Characteristics of folic acid-binding protein in folate-deficient serum. Blood, 42, 291-301.

Waxman, S., and Schreiber, C. (1974). Isolation and characterization of folate binding protein(s) (FABP) from human milk by affinity chromatography (Abstract). Blood, 44, 911.

Zamierowski, M., and Wagner, C. (1974). High molecular weight complexes of folic acid in mammalian tissues. Biochemical and Biophysical Research Communications, 60, 81-87.

Zettner, A., and Duly, P. E. (1974). New evidence for a binding principle specific for folates as a normal constituent of human serum. Clinical Chemistry, 20, 1313-1319.

Requests for reprints to: Professor A. V. Hoffbrand, Department of Haematology, The Royal Free Hospital, Pond Street, Hampstead, London NW3 2QG, UK. 